\title{
Effectiveness of Online Learning during The Covid-19 Pandemic in Deli Serdang District Junior High School
}

\author{
Ahmad Mukhlasin, Mansyur Hidayat Pasaribu \\ STAI Jam'iyah Mahmudiyah Indonesia \\ SMP Negeri 1 Hamaparan Perak, Indonesia \\ ahmadmukhlasin231216@gmail.com/mansyurpasaribu@yahoo.co.id
}

\begin{tabular}{ll}
\hline Article History & Received : December $13^{\text {th }} 2020$ \\
& Revision : February $27^{\text {th }} 2021$ \\
& Publication : March $30^{\text {th }} 2021$ \\
\hline
\end{tabular}

\begin{abstract}
The purpose of this study is to explain about the effectiveness of online learning during the covid-19 pandemic in junior high school in Deli Serdang Regency, North Sumatra, this research method is descriptive qualitative and conducted with online media, the result of this study is: The implementation of online learning in SMP Deli Serdang district contributes to habituation efforts in using online applications that are likely to grow in the future. Teachers' ability to choose learning methods and their skills in operationalizing online learning applications strongly supports the online learning process. All teachers of Deli Serdang District Junior High School are able to operate WhatsApp application even though it is not yet maximized. This online learning is considered ineffective in Deli Serdang Junior High School, because there are still obstacles such as: 1) quotas that must be purchased by students, 2) the assignments given always accumulate, 3) the conditions and circumstances of the student's home are different so that students must be divided into focus with other things, 4) understanding and explanation of the teacher has been delivered but less so directly understood by students so that they need help from others, 5) intrinsic motivation of students, lack of motivation to learn from parents. The success of the online learning system depends largely on some components of learning itself, whether from students, learning resource teachers, or information technology. .
\end{abstract}

Keywords: Effectiveness, Online Learning, Covid-19

\section{INTRODUCTION}

The development of education is supported by several things such as technological advances, educational technology used by educational actors to facilitate the educational process such as teaching and learning and in terms of improving the quality of education. At this time, at the time of this pandemic, online learning or PJJ (distance learning) is an easy choice to do such learning. The learning process and delivery of students' lessons is assisted by technology. Distance learning (PJJ) or online (Online) began on March 16, 2020, here all 
children in Indonesia including junior high school students in Deli Serdang - Sumut began to learn from their homes without the need to come to school. Speaking of learning conducted with PJJ or Online, it is very necessary to master tenknology so that educational activities such as teaching and learning run well.

Designing a learning strategy by innovating highly is the key to successful learning during this pandemic. Not only designing a unique strategy but preparing and concocting materials that can be absorbed by doing distance learning, and conducting learning with methods that really attract the attention of students so that they do not get tired of following online learning and not become a psychic burden.

In addition, the implementation of Online learning during COVID-19 is a support and discipline from all parties, . Therefore, from the management of madrasah as the manager in the madrasah is very necessary to carry out a strategy or scheme to organize the learning conducted with the online media, so that all parties follow the rules of the game from the management of madrasah tersbeut, thus will create a satisfactory learning success. Such management can be like a systematic schedule, structured and simple to facilitate communication of parents with madrasah so that all students who study at home can be monitored effectively.

The purpose of learning is one of the indicators of the effectiveness of learning. The learning objectives will be achieved to the maximum so it can be said that the effectiveness of learning is achieved. In other respects, the effectiveness of learning is also supported by the activeness of learners in following the learning, with this the learning objectives will be achieved well and students can absorb the lesson material and practice it.

\section{LITERATURE REVIEW}

\section{Learning Concepts}

Learning is a broad process that is experienced in all people and is responsible and lasts a lifetime, from the baby to the burrow. A more general or broad sense of education as expressed by (Reber, 1988) which defines learning in the following two senses; (1) Learning as the process of acquiring knowledge. Learning is as a process of acquiring science; (2) Learning is a relatively permanent change in response potentialitywhich occurs as a result of reonfeced practice". Learning is an improvement of the ability to react relatively long from the results of practice done continuously. (Winkel, 1983) defines learning as follows: "belaja mupakan process in the self that leads to mastering the knowledge of habits, skills or attitudes where all these things are obtained, stored and practiced so that it will give birth to behavior as appropriate as what it knows.

In the learning process according to (Syahidin \& Milastri, 2010) students desperately need experience that can be captured by the five senses. The 
experience can be obtained through educational media. But in its use there must be something to do with the material taught. The theory of connectionism holds that learning is an activity that forms an association (connection) between the impression of the five senses and the tendency to act. Learning to have some definition, learning is a process of effort made by individuals to obtain a new behavior change as a whole. As a result of individual experiences and interactions with their environment. Whereas according to some experts explained in (Dkk, 1994) learn as follows:

According to Gagne learning occurs when a stimulus along with the content, memory influences the student in such a way that his behavior in overcoming and dealing with something over time.

According to Morgan, learning is a lasting change that can be seen from the behavior that can be from the results of practice and the experience that he experienced.

According to Witheringthon learning is a thing that changes in him and his personality which is a new way of reaction such as attitude, proficiency, habits, cleverness and an understanding.

From these definitions, learning can be interpreted as a process of behavior change that occurs in learning situations, this is characterized by the motives set or accepted by learners, and this change in behavior is something obtained from what he experienced himself in interaction with the surrounding environment. Learning on the cognitive aspect besides behavioris (behavior) is learning is a behavior in seeking knowledge, proficiency, understanding, attitudes, and habits that are stored and implemented so that it will result in changes in knowledge and actions.

In addition to the term learning, there is also a known learning. Learning expressed by (Dimyati, 1998) as an effort to provide guidance and direction conducted by (educators / teachers) in the learning process of learners. As an example where the teacher explains how a child who has to study at elementary school level for 6 years, who after that accelerated his education in junior high school for 3 years, and continued back in high school for 3 years and will eventually continue to college in accordance with what is in demand by the child.

Learning is a two-way process, in which teachers who act as teachers and learners and students act as taught ones. A teacher teaches students by using educational theory and the principle of education is the main thing in the success of an education term peroses learning mamang less popular than the term learning because the term process of learning to teach pressures on the motivation of learners to be active (learn how to learn) so that they can find their own way of learning that is right for him. If philosophically in the learning process is stated give fishing rods and teach how to fish and do not give to them fish that are ready to eat. So here finally the learners must be able to find and build their own knowledge. 
The learning process is essentially a communication process, which is the process of delivering messages from sources through media channels / certain to the recipient of the message. Messages, message sources, channels /tools and who receive messages are a component of the communication process. The message is the content of the lesson or what is in the curriculum. The source of the message could be students, teachers, others or book authors and publishers. The channel is an educational medium and the recipients of the message are students or teachers.

\section{Implementation of Learning during the Covid 19 Pandemic}

Students are human children who have personality, motivation, self-esteem, and have other personal knowledge with others, then the use of media in the learning process is done using a humanist approach. (Syahidin \& Milastri, 2010) By paying attention to the complexity and uniqueness of the learning process, the accuracy of the selection of media and learning methods will greatly affect the learning outcomes of learners.

On March 24, 2020 the Minister of Education and Culture of the Republic of Indonesia issued SE Number 4 of 2020 concerning the Implementation of Education Policy in the Emergency Period of the Spread of Covid-19. In the letter mentioned that the learning process is done from home online / remotely and must provide a meaningful learning experience for students. Life skills such as handling the Covid-19 pandemic are the focus of long-distance travel.

(Patria \& Yulianto, 2011) suggests there are several learning methods that are done when learning from home, including online learning. Online learning is a method of learning that uses technology and internet networks ranging from the use of Whatsapp, Google Classroom, Zoom or other applications. Online learning is done by utilizing internet technology with a distance learning system, so that learning and teaching activities (KBM) are not conducted face-to-face. Online learning can be done using several media, either print media (modules) or nonprinting (audio or video), computer or internet, radio and television broadcasts.

Online other words in the network, according to the Great Dictionary of Indonesian Language (KBBI) Kemendikbud pusat, which means connected through computer networks, the internet, and some of them. So, teaching and learning activities of teachers, lecturers, students, and students are now conducted through internet networks and applications that can support online learning that includes the learning process, assignments and others (O.I Handarini \& S.S Wulandari, 2020). There are several applications that can be used to help with defense activities, such as Zoom, Whatsapp, Web Blog, Bib and others. Aspects of learning media include product aspects, process aspects, attitude aspects, and applications. The online application is an application used for online learning that aims to make students active and independent. By using online apps such as WhatsApp groups, Google, and learning apps students can access online learning and complete 
learning. The online application aims to train student independence and student activity (Oknisih et al., 2019).

Some of the definitions of online learning that have been explained concluded that online learning is a learning activity that is done by utilizing digital devices and the internet to make learning more interesting, creative and independent. Online learning includes the delivery of materials and information, assignments and active interactions between teachers and students during the online learning process.

Online learning is one of the learning methods that the learning process through or based on electronics. The use of media whose defenders are networks and computers. Online learning (Online) is a teaching and learning peroses that uses a network with flexibility, accessibility, connectivity, and the ability to generate various types of interactions in learning conducted. In online learning there are many choices of online applications that can support online learning itself and each online learning application has different systems and ways of working including Google Classroom, Google Meeting, Zoom, Whatsapp, Youtube, Edmodo and others. For distance learning, flexibility is required, utilizing what students have and improving activities between teachers and students, there is assessment and feedback, and communicating reciprocally or bidirectionally, students learn at their own pace and ability and teachers can monitor student activities even at long distances.

\section{The Role of Teachers in Online Learning}

The high quality of education is determined by one of the factors, namely teachers, so teacher improvement is very important and always din improve the quality of education. When everyone is questioning about the world of education, the teacher picture must be involved in discussions, especially when it comes to formal education in schools. This is undeniable because formal educational institutions are the world of teacher life. the most time teachers are in school.

A very dominant factor in formal education is teachers in general because for students teachers are often used as role models and even become selfidentification figures. And the element that is very influential in schools is teachers, where teachers are key to achieving educational goals in schools. The success of the implementation of education is strongly influenced by the readiness of teachers in preparing their students or students through learning activities. However, the teacher's professional ability greatly affects the teacher's performance and work spirit.

The role in general is the action to carry out something that has been planned and agreed together in order to achieve the goals or targets that have been determined so as to have a positive impact for everyone. In line with the description of the Role according to (Usman, 2002) is "activities that boil down to 
the activity, action, or action of the mechanism of a system. not just an activity but a planned activity and to achieve the objectives of the activity".

In Law No. 20 of 2003 CHAPTER XI article 39, it is mentioned that educators or teachers are professionals who have the task to plan and then carry out the teaching and learning process, assess the learning outcomes of children, conduct guidance and training. Teachers are educators in charge of the union of primary and secondary education. As an educator, teachers have the main task as in Law No. 14 of 2005 article 35: Planning learning, carrying out quality learning processes, as well as assessing and evaluating learning outcomes, Improving and developing academic qualifications, acting objectively and not descriptively upholding the laws and regulations, laws and codes of ethics of teachers, as well as religious and ethical values, maintaining and fostering the unity and unity of the nation.

(Djamarah, 2005) stated that the position of teacher has a lot of tasks, both tied outside the service and in the service in the form of a devotion. The teacher's job is not only as a job, but also as a public and humanitarian task. Teacher's duty as a job demands teachers to continuously improve their professionalism in accordance with the development of science and technology. In addition, the activities of educating, teaching and training students are the duties of teachers as a profession of teacher duty in this regard related to providing knowledge (transfer of knowledges), The duty of teachers as professionals demands continuous improvement of teacher skills and quality. A professionally qualified teacher, who knows deeply about what he teaches, is capable of teaching it effectively and efficiently, and the teacher has a strong personality. The teacher's next assignment is a humanitarian task. This task is one aspect of the teacher's task. This side cannot be simply ignored, because a teacher must engage with life in society with social interaction.

In the implementation of learning conducted by teachers refers to Law Number 14 of 2005 article 20 on the obligation of teachers, namely making learning plan, conducting the process in quality, as well as providing assessment and evaluating the results of the learning. The role of teachers in online learning is an effort made by the school in providing better and easier to understand learning. The role of teachers in online learning, all classroom teachers use the WhatsApp application. This app was chosen because the features are easy to operate. The use of WhatsApp application is considered effective for learning. The implementation of online learning also refers to Permendikbud number 119 of 2014 on the implementation of distance education (PJJ) at the primary and secondary education levels.

Teachers as remote classroom managers have a role to play in planning, preparing, implementing and evaluating distance learning processes. Participants are given alternatives to add knowledge insights by downloading teaching 
materials, working on the tasks given in the file, and discussing with a group of friends about the materials that have been given.

\section{METHOD}

This research was conducted by descriptive qualitative method with approach. Qualitative research is used by referring to opinions (Sugiyono, 2009),qualitatical research methods are naturalistic research because the narural research without settings and collected data are analyzed qualitatively. Qualitative research is considered suitable to describe how the current condition and the background of research is the effectiveness of online learning during the Covid 19 pandemic in Deli Serdang Junior High School. The subjects and objects in this study are the parties who are tekait in the context of SMP Deli Serdang. This research instrument is a guideline for interviews conducted online through the WhatsApp application.

\section{RESULTS AND DISCUSSION}

The implementation of online learning at SMP Deli Serdang went smoothly, but was felt by some teachers and students less than conventional face-to-face learning. Sometimes non-simultaneous communication makes it difficult for some students to ask questions during the learning process. Poor communication causes the material to become elusive. The phenomenon that occurred in Deli Serdang District Junior High School runs that teachers are more focused on giving tasks than materials. In addition, the geographical location and geographical conditions of students' residences that vary from one to another sometimes make the internet connection poor, thus disrupting the audio and display/visualization of teaching materials. Online learning at SMP Kabupaten Deli Serdang runs less effectively because some applications that have a smooth connection are sometimes wasteful quotas.

The findings about the effectiveness of online learning during the covid 19 pandemic in Deli Serdang Junior High School can be seen from the learning outcomes of deli serdang junior high school students running varied, ranging from unsatisfactory, quite to good. It found that the students' learning outcomes were less satisfactory because the material understood was less than face-to-face learning in class. However, there are some students of Deli Serdang Junior High School whose learning results are good because they are used to online learning.

Online learning contributes to habituation efforts in using online applications that are likely to grow in the future. According to the informant / teacher of SMP Deli Serdang, the online learning model slightly gives a role to the achievement of the final score in student learning, according to him, with online learning, the level of confidence of students to ask or respond is higher than when face-to-face.

The success of the online learning system depends largely on some components of learning itself, whether from students, learning resource teachers, or information technology. These components are integrated in order to produce 
qualified graduates in accordance with the educational objectives themselves. Online learning is considered by some informants /teachers to be effective if applied during the covid-19 pandemic because it relates to health protocols.

The next finding about the effectiveness of online learning during the covid 19 pandemic in Smp Kabupaten Deli Serdang is according to some teachers that this learning model is ineffective, because there are some lessons that are difficult to understand when implementing online learners and the second statement, Online learning is less effective because of some obstacles. That is, there are learning materials that can not be understood through online learning, especially in lessons that require hands-on practice. Moreover, with the large number of students that can lead to less controlled learning and supervision conducted by teachers. And if this online learning is applied in the long run without being interspersed with other learning models, the online learning model can cause a sense of saturation in the student.

Online learning is considered ineffective by some teachers of SMP Deli Serdang Regency, they argue that the online learning model is also inseparable from the obstacles faced by both teachers and students, the opinion on the obstacles faced in online learning is as follows: First, the quota that must be purchased by students, the tasks given always accumulate, because the conditions and circumstances of the student's home are different so that students must be divided into focus with other things, understanding and explanation of teachers has been conveyed but less so directly understood by students so that they need help from others, Second, the obstacles faced are in addition to internet access that is not the same in every place, students also need intrinsic motivation in themselves, lack of motivation to learn from parents, lack of parental assistance and parents stuttering technology (gaptek) because it is old age so it is not able to operate smartphones. This can hinder the implementation of online shoppers in Deli Serdang District Junior High School

Third, the obstacles faced by deli serdang junior high school students include signals, and inadequate internet quota. Residential environments in cities or villages also affect the implementation of online learning, due to the limited range of signals making it difficult for those who are not reachable to the signal.

In online learning, students are often found to be less active in the learning process. In online learning students are less able to convey their aspirations and opinions, so in the end online learning is felt no more pleasant than face-to-face learning. Teachers' ability to choose learning methods and their skills in operationalizing online learning applications strongly supports the online learning process. All teachers of SMP Deli Serdang regency are able to operate WhatsApp application even though it is not yet maximum and all teachers in choosing teaching materials and methods are in accordance with the curriculum. Seen from the Learning Implementation Plan (RPP).

\section{CONCLUSION}

The implementation of online learning at SMP Deli Serdang district contributes to habituation efforts in using online applications that are likely to grow in the future. Teachers' ability to choose learning methods and their skills in 
operationalizing online learning applications strongly supports the online learning process. All teachers of Deli Serdang District Junior High School are able to operate WhatsApp application even though it is not yet maximized.

This online learning is considered ineffective in Deli Serdang Junior High School, because there are still obstacles such as: 1) quotas that must be purchased by students, 2) the assignments given always accumulate, 3) the conditions and circumstances of the student's home are different so that students must be divided into focus with other things, 4) understanding and explanation of the teacher has been delivered but less so directly understood by students so that they need help from others, 5) intrinsic motivation of students, lack of motivation to learn from parents.

The success of the online learning system depends largely on some components of learning itself, whether from students, learning resource teachers, or information technology. These components are integrated in order to produce qualified graduates in accordance with the educational objectives themselves. Online learning is considered by some informants /teachers to be effective if applied during the covid-19 pandemic because it relates to health protocols. .

\section{REFERENCES}

Dimyati. (1998). Belajar dan Pembelajaran. PT Rineka Cipta.

Djamarah, S. . (2005). Guru Dan Anak Didik Dalam Interaksi Anak Didik. PT RINEKA CIPTA.

Dkk, T. R. (1994). Pendekatan dalam Proses Belajar Mengajar. Rosdakarya.

O.I Handarini, \& S.S Wulandari. (2020). Pembelajaran Daring sebagai Upaya Study From Home (SFH) Selama Pandemi Covid 19. Jurnal Pendidikan Administrasi Perkantoran (JPAP), 8(3), 496-503.

Oknisih, Nur. Wahyuningsih, Yull, \& Suyoto. (2019). Penggunaan Aplen (Aplikasi Online) sebagai Upaya Kemandirian Belajar Siswa. Prosiding Seminar Nasional Pendidikan Dasar, 1, 477-483. http://eproceedings.umpwr.ac.id/index.php/semnaspgsd/article/view/1056

Patria, L., \& Yulianto, K. (2011). Pemanfaatan Facebook Untuk Menunjang Kegiatan Belajar Mengajar Online Secara Mandiri. Prosiding Seminar Nasional FMIPAUT 2011. http://repository.ut.ac.id/id/eprint/2305

Reber, A. . (1988). The Penguin Dictionary of Psychology. Penguin Books Australia Ltd.

Sugiyono. (2009). Metode Penelitian Kuantitatif, Kualitatif dan R\&D. alfabeta.

Syahidin, \& Milastri. (2010). Media Pembelajaran. Media Persada.

Usman, N. (2002). Konteks Implementasi Berbasis Kurikulum. PT Raja Gravindo Persada.

Winkel. (1983). Psikologi Pendidikan. Gramedia. 